\title{
Fluorinated Beta-diketo Phosphorus Ylides Are Novel Efflux Pump Inhibitors in Bacteria
}

\author{
ANNAMÁRIA KINCSES ${ }^{1}$, ÁGNES MÍRA SZABÓ ${ }^{1}$, RYOSUKE SAIJO $^{2}$, GENKI WATANABE ${ }^{2}$, \\ MASAMI KAWASE ${ }^{2}$, JOSEPH MOLNÁR ${ }^{1}$ and GABRIELLA SPENGLER ${ }^{1}$ \\ ${ }^{1}$ Department of Medical Microbiology and Immunobiology, Faculty of Medicine, \\ University of Szeged, Szeged, Hungary; \\ ${ }^{2}$ Faculty of Pharmaceutical Sciences, Matsuyama University, Matsuyamas, Japan
}

\begin{abstract}
Background: One of the most important resistance mechanisms in bacteria is the increased expression of multidrug efflux pumps. To combat effluxrelated resistance, the development of new efflux pump inhibitors is essential. Materials and Methods: Ten phosphorus ylides were compared based on their MDRreverting activity in multidrug efflux pump system consisting of the subunits acridine-resistance proteins $A$ and $B$ (Acr A and $A(r B)$ and the multidrug efflux pump outer membrane factor TolC (TolC) of Escherichia coli K-12 AG100 strain and its AcrAB-TolC-deleted strain. Efflux inhibition was assessed by real-time fluorimetry and the inhibition of quorum sensing (QS) was also investigated. The relative gene expression of efflux $Q S$ genes was determined by realtime reverse transcriptase quantitative polymerase chain reaction. Results: The most potent derivative was $\mathrm{Ph}_{3} \mathrm{P}=\mathrm{C}\left(\mathrm{COC}_{2} \mathrm{~F}_{5}\right) \mathrm{CHO}$ and its effect was more pronounced on the AcrAB-TolC-expressing E. coli strain, furthermore the most active compounds, $\mathrm{Ph}_{3} \mathrm{P}=\mathrm{C}\left(\mathrm{COCF}_{3}\right) \mathrm{OMe}$, $\mathrm{Ph}_{3} \mathrm{P}=\mathrm{C}\left(\mathrm{COC}_{2} \mathrm{~F}_{5}\right) \mathrm{CHO}$ and $\mathrm{Ph}_{3} \mathrm{P}=\mathrm{C}\left(\mathrm{COCF}_{3}\right) \mathrm{COMe}$, reduced the expression of efflux pump and $Q S$ genes. Conclusion: Phosphorus ylides might be valuable EPI compounds to reverse efflux related MDR in bacteria.
\end{abstract}

Multidrug resistance (MDR) is a serious problem for the treatment of various diseases, such as bacterial and fungal infections and cancer, due to reduction or deficit response of

Correspondence to: Gabriella Spengler, Department of Medical Microbiology and Immunobiology, Faculty of Medicine, University of Szeged, Dóm tér 10, H-6720 Szeged, Hungary. Tel: +36 62545115, Fax: +36 62545113, e-mail: spengler.gabriella@med.uszeged.hu

Key Words: Phosphorus ylides, multidrug resistance, bacterial AcrAB-TolC, efflux pump, quorum sensing. microorganisms as well as cancer cells to applied chemotherapeutic agents $(1,2)$.

One of the major mechanisms of MDR is the overexpression of efflux pumps (EPs), which reduces the accumulation of toxic agents. In bacteria the resistance nodulation division (RND) transporters have a great impact on MDR phenotype. The major cause for the MDR phenotype is due to overexpression of efflux pumps that are part of the RND family of transporters, for example the acridineresistance proteins $\mathrm{A}$ and $\mathrm{B}$ (AcrA and AcrB) and the multidrug efflux pump outer membrane factor TolC (TolC) AcrAB-TolC system (1). These efflux pumps have the ability to recognize and extrude a large variety of unrelated antibiotics from the periplasmic space of the cell envelope, or from the cytoplasm. The energy required for the operation of the efflux pump is provided by the proton motive force created by the proton gradient resulting from electron transport (3).

The quorum-sensing system (QS) in bacteria is a regulatory system that controls gene expression depending on the density of the bacterial cell population. A transcriptional regulator (LuxR homolog), signal synthase (LuxI homolog) and autoinducer (acyl homoserine lactone) are crucial for the QS in most Gram-negative bacteria. SdiA, an E. coli LuxR homolog, has a great impact on the colonization of $E$. coli $(4,5)$. SdiA is a homolog of QS regulators that detects $N$-acylhomoserine lactone (AHL) signals from other bacteria. SdiA represses the expression of virulence factors by interacting with unknown stationaryphase signals in E. coli O157:H7, and enhances multidrug resistance by activating MDR efflux pumps in E. coli (6).

Organic compounds of phosphorus ylides (P-ylides) are a fascinating class of compounds (7). The biological activity of P-ylides related to their ATP-binding cassette subfamily B member 1 (ABCB1)-modulating activity in mouse lymphoma cells has already been described (8), however, additional information is needed to describe their valuable biological activities in other aspects. 
In this article, we report the MDR-modulating activities of P-ylides in bacteria related to the inhibition of efflux activity and QS.

\section{Materials and Methods}

Compounds. The synthesis of P-ylides was described previously (8) and the structures of the P-ylides (compounds 1-10) screened for their MDR-modulating activities are shown in Table I. The compounds were dissolved in dimethyl sulfoxide (DMSO) for the experiments.

Acridine orange (AO), ethidium bromide (EB), and LB broth were purchased from Sigma-Aldrich Chemie GmbH (Steinheim, Germany). Modified LB agar (LB*) contained $5 \mathrm{~g}$ yeast extract, 10 g trypton, $10 \mathrm{~g} \mathrm{NaCl}, 1 \mathrm{~g} \mathrm{~K}_{2} \mathrm{HPO}_{4}, 0.3 \mathrm{~g} \mathrm{MgSO}_{4} .7 \mathrm{H}_{2} \mathrm{O}$ and 36 mg FeNaEDTA in 1.01 of distilled water. Mueller Hinton broth was purchased from Scharlau Chemie S.A. (Barcelona, Spain).

Bacterial strains. Wild-type E. coli K-12 AG100 strain [argE3 thi-1 rpsL xyl mtl $\Delta$ (gal-uvrB) supE44] expressing the AcrABTolC EP at its basal level and its AcrAB-TolC-deleted mutant strain (E. coli $\mathrm{K}-12$ AG100A). The strains were kindly provided by Professor Dr. Hiroshi Nikaido (Department of Molecular and Cell Biology and Chemistry, University of California, Berkeley, CA, USA).

Strains used for QS tests: Chromobacterium violaceum 026 (CV026) as sensor strain; Sphingomonas spp. EZF 10-17 (Sphingomonadaceae) isolated from a grapevine crown gall tumor (used as AHL producer), this strain induced pigment production by CV026 and proved to be efficient for the study of QS interactions; Enterobacter cloaceae 31298 (clinical wound isolate, used as AHL producer).

Determination of minimum inhibitory concentrations. The minimum inhibitory concentrations (MICs) of P-ylides were tested according to Clinical and Laboratory Standard Institute guidelines (9).

Real-time accumulation assay by Roche LightCycler real-time thermocycler. The effect of the studied compounds on the realtime accumulation of EB was assessed by an automated EB method (10), using a LightCycler real-time thermocycler (LightCycler 1.5; Roche, Indianapolis, IN, USA). Briefly, an aliquot of an overnight culture of the strain in LB medium was transferred to fresh LB medium and incubated until it reached an optical density (OD) of 0.6 at $600 \mathrm{~nm}$. It was then washed with phosphate-buffered saline (PBS; $\mathrm{pH} 7.4$ ) and centrifuged at $13,000 \times g$ for $3 \mathrm{~min}$, the pellets re-suspended in PBS ( $\mathrm{pH} \mathrm{7.4)}$ and the OD adjusted to 0.6 at $600 \mathrm{~nm}$. The compounds were added individually at different concentrations (in double concentrated form) in $5 \mu 1$ volumes of their stock solutions to 45 $\mu \mathrm{l}$ of EB solution of $2 \mathrm{mg} / 1$ in PBS. Then, $10 \mu \mathrm{l}$ of the EB solution containing the compound were transferred into standard glass capillary tubes of $20 \mu \mathrm{l}$ maximum volume (Roche) and 10 $\mu \mathrm{l}$ of bacterial suspension (OD of 0.6 at $600 \mathrm{~nm}$ ) was added to the capillaries. The capillaries containing the samples were placed into a carousel (Roche) and the fluorescence was monitored at the FL-2 channel every minute on a real-time basis.

From the real-time data, the activity of the compound, namely the relative fluorescence index (RFI) of the last time point (minute
30) of the EB accumulation assay was calculated according to the formula:

$$
R F I=\frac{R F_{\text {treated }}-R F_{\text {untreated }}}{R F_{\text {untreated }}}
$$

where $R F_{\text {treated }}$ is the relative fluorescence at the last time point of the EB retention curve in the presence of an inhibitor, and $R F_{\text {untreated }}$ is the relative fluorescence at the last time point of the EB retention curve of the untreated solvent control (DMSO).

Assay for QS inhibition. LB* was used for these experiments. The sensor strain $C$. violaceum 026 (CV026) and the AHL producer strains EZF 10-17 Sphingomonas spp. (Sphingomonadaceae) or E. cloaceae 31298 were inoculated as parallel lines and incubated at room temperature $\left(20^{\circ} \mathrm{C}\right)$ for $24-48 \mathrm{~h}$. QS inhibition was monitored by agar diffusion method. Filter paper discs $(7.0 \mathrm{~mm}$ in diameter) were impregnated with $10 \mu \mathrm{l}$ of stock solutions of the compounds in DMSO (10 mg/ml in DMSO). The discs were placed between the parallel lines of sensor and AHL producer strains on the surface of the nutrient agar. The plates were incubated at room temperature for a further 24-48 $\mathrm{h}$ and the interactions between the strains and compounds were evaluated for the reduction in size of the zone of pigment production and the zone of growth inhibition of the affected strains, in millimeters. AO was applied as positive control (11).

Expression analyses of genes by real-time reverse transcriptase quantitative polymerase chain $(R T-q P C R)$ reaction. Bacteria were cultured in LB broth and were incubated overnight at $37^{\circ} \mathrm{C}$ with shaking. On the day of RNA isolation, the bacterial suspensions (OD of 0.6 at $600 \mathrm{~nm}$ ) were transferred to $10 \mathrm{ml}$ tubes in $3 \mathrm{ml}$ aliquots and $50 \mu \mathrm{g} / \mathrm{ml}$ of compounds were added to the tubes which were the incubated at $37^{\circ} \mathrm{C}$. At intervals of 4 and $18 \mathrm{~h}$ of culture, the tubes were centrifuged at $12,000 \times g$ for $2 \mathrm{~min}$. Pellets were suspended in $100 \mu \mathrm{lE}$ buffer containing $1 \mathrm{mg} / \mathrm{ml}$ lysozyme by vigorous vortexing and were incubated at $37^{\circ} \mathrm{C}$ for $10 \mathrm{~min}$. The total RNA was isolated in an RNase-free environment using NucleoSpin RNA kit (Macherey Nagel, Germany) according to the manufacturer's instructions. Purified RNA was stored in RNasefree water in nuclease-free collection tubes and was maintained at $-20^{\circ} \mathrm{C}$ until quantification was performed. The concentration of the extracted RNA templates was assessed by spectrophotometry at $260 \mathrm{~nm}$.

Expression of the $a c r A, a c r B$, multiple antibiotic resistance protein $\mathrm{R}$ ( $\operatorname{mar} R$ ) and quorum-sensing transcriptional activator (sdiA) genes was studied by reverse transcription of total RNA. The data obtained for gene targets were normalized against the $E$. coli house-keeping gene glyceraldehyde-3-phosphate-dehydrogenase (gapdh) measured in the same sample. Real-time quantification of the RNA templates by real-time one-step RT-qPCR was performed in a CFX96 Touch realtime PCR detection system (Bio-Rad, Hercules, CA, USA) strictly adhering to the manufacturer recommendations of the SensiFAST ${ }^{\text {TM }}$ SYBR No-ROX One-Step Kit (Bioline GmbH, Luckenwalde, Germany). Briefly, each well of 96-well microtiter plates contained, in a final volume of $20 \mu \mathrm{l}, 10 \mu \mathrm{l}$ of the $2 x$ SensiFAST ${ }^{\mathrm{TM}}$ SYBR NoROX One-Step Mix, $0.2 \mu$ l Reverse Transcriptase, $0.4 \mu$ l RiboSafe RNase Inhibitor, $5.4 \mu$ diethylpyrocarbonate-treated water, $500 \mathrm{nM}$ of each primer and approximately $20 \mathrm{ng}$ of total RNA in RNAase-free water. Thermal cycling was initiated with a denaturation step of $5 \mathrm{~min}$ 
Table I. Structures of P-ylides (compounds 1-10).

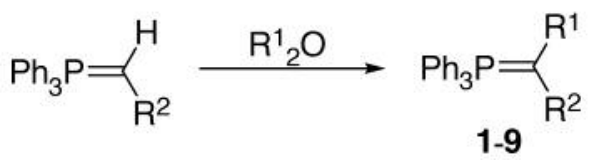

\begin{tabular}{lcc}
\hline Compound & $\mathrm{R}^{1}$ & $\mathrm{R}^{2}$ \\
\hline $\mathbf{1}$ & $\mathrm{COCF}_{3}$ & $\mathrm{CN}$ \\
$\mathbf{2}$ & $\mathrm{COCF}_{3}$ & $\mathrm{OMe}$ \\
$\mathbf{3}$ & $\mathrm{COCF}_{3}$ & $\mathrm{COPh}$ \\
$\mathbf{4}$ & $\mathrm{COCF}_{3}$ & $\mathrm{CHO}$ \\
$\mathbf{5}$ & $\mathrm{COCF}_{3}$ & $\mathrm{COMe}$ \\
$\mathbf{6}$ & $\mathrm{COCF}_{3}$ & $\mathrm{CO} 2 \mathrm{Et}$ \\
$\mathbf{7}$ & $\mathrm{COC}_{2} \mathrm{~F}_{5}$ & $\mathrm{COPh}$ \\
$\mathbf{8}$ & $\mathrm{COC}_{3} \mathrm{~F}_{7}$ & $\mathrm{COPh}$ \\
$\mathbf{9}$ & $\mathrm{COCH}_{3}$ & $\mathrm{CN}$ \\
$\mathbf{1 0}$ & $\mathrm{H}$ & $\mathrm{CN}$ \\
\hline
\end{tabular}

at $95^{\circ} \mathrm{C}$, followed by 40 cycles each of $10 \mathrm{~s}$ at $95^{\circ} \mathrm{C}, 30 \mathrm{~s}$ at $57^{\circ} \mathrm{C}$ and $20 \mathrm{~s}$ at $72^{\circ} \mathrm{C}$.

The forward and reverse primers used for assessment of the activity of the transporter genes $\operatorname{acr} A, \operatorname{acr} B$, the regulator $\operatorname{mar} R$ and the QS regulator $s d i A$ are shown in Table II.

\section{Results}

Compounds 1-10 did not have any antibacterial effect on the AcrAB-TolC-expressing E. coli AG100 (MDR) strain nor its AcrAB-TolC-deleted progeny E. coli AG100A (EP-deleted strain) (MIC above $100 \mu \mathrm{g} / \mathrm{ml}$ ), except for $\mathbf{6}$, which had a mild, non-significant effect on the EP-deleted strain (MIC=50 $\mu \mathrm{g} / \mathrm{ml})$.

The activity of the compounds was compared based on the relative final fluorescence index (RFI) of the real-time accumulation curves (Table III).

In the case of real-time EB accumulation by Light Cycler thermocycler, the amount of EB accumulated by cells is higher if the difference between $\mathrm{RF}_{\text {treated }}$ and $\mathrm{RF}_{\text {untreated }}$ is greater, therefore, the degree of inhibition of the EP system by the compound becomes greater.

The majority of the $\mathrm{P}$-ylides were found to inhibit the AcrAB-TolC system of $E$. coli except $\mathrm{Ph}_{3} \mathrm{P}=\mathrm{C}\left(\mathrm{COCF}_{3}\right) \mathrm{COPh}$ (3), $\mathrm{Ph}_{3} \mathrm{P}=\mathrm{C}\left(\mathrm{COC}_{2} \mathrm{~F}_{5}\right) \mathrm{COPh}(7)$ and $\mathrm{Ph}_{3} \mathrm{P}=\mathrm{C}\left(\mathrm{COC}_{3} \mathrm{~F}_{7}\right) \mathrm{COPh}$ (8), which had little or no effect on the intracellular $\mathrm{EB}$ accumulation in the E. coli AG100 and the AG100A strains. Among the P-ylide series, $\mathrm{Ph}_{3} \mathrm{P}=\mathrm{C}\left(\mathrm{COCF}_{3}\right) \mathrm{OMe}$ (2), $\mathrm{Ph}_{3} \mathrm{P}=\mathrm{C}\left(\mathrm{COCF}_{3}\right) \mathrm{CHO}$ (4) and $\mathrm{Ph}_{3} \mathrm{P}=\mathrm{C}\left(\mathrm{COCF}_{3}\right) \mathrm{COMe}$ (5) exhibited strong AcrAB-TolC pump-inhibiting properties compared to the AcrAB-TolC pump-deficient mutant strain. The most potent derivative was $\mathbf{4}$ and its effect was more
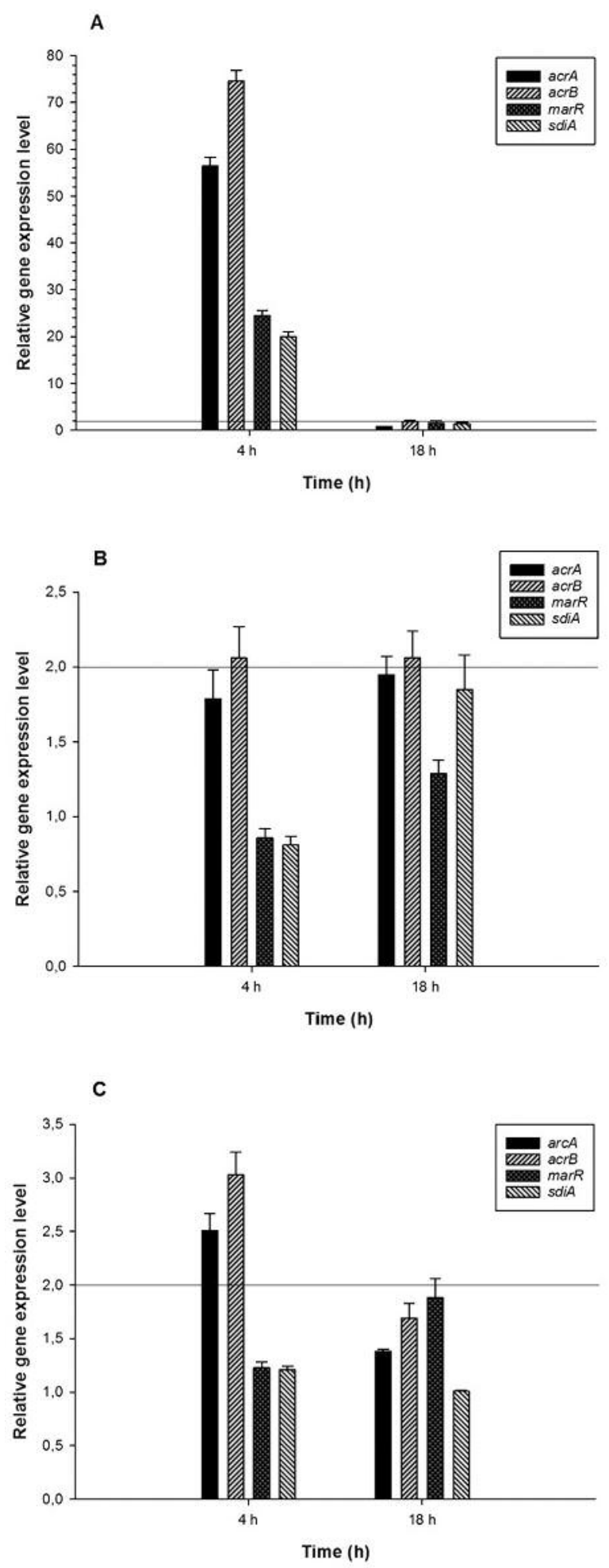

Figure 1. Relative gene expression levels of the genes of the acridine resistance protein $A(a c r A)$, acridine resistance protein $B(a c r B)$, multiple antibiotic resistance protein $R$ (marR) and quorum-sensing transcriptional activator (sdiA) in the presence of compounds 2 (A), 4 $(B)$, and $5(C)$ after 4 and 18 h exposure in $L B$. The line denotes the threshold value, which was set at a two-fold increase in transcripts. 
Table II. Forward and reverse primers used for assessment of the activity of the transporter genes acrA and acrB, the regulator marR and the quorum-sensing regulator sdiA of Escherichia coli AG100.

\begin{tabular}{|c|c|c|c|c|}
\hline Gene & Full name & Primer sequence ( $5^{\prime}-3$ ') & $\begin{array}{l}\text { Amplicon } \\
\text { size (bp) }\end{array}$ & Reference \\
\hline acrA & Acridine-resistance protein A & CTTAGCCCTAACAGGATGTGTTGAAATTACGCTTCAGGAT & 189 & $(12)$ \\
\hline$a c r B$ & Acridine-resistance protein $\mathrm{B}$ & CGTACACAGAAAGTGCTCAACGCTTCAACTTTGTTTTCTT & 183 & $(12)$ \\
\hline $\operatorname{marR}$ & Multiple antibiotic-resistance protein $\mathrm{R}$ & AGCGATCTGTTCAATGAAATTTCAGTTCAACCGGAGTAAT & 170 & (12) \\
\hline sdiA & Quorum-sensing transcriptional activator & CTGATGGCTCTGATGCGTTTATCTGGTGGAAATTGACCGTATT & 163 & This study \\
\hline gapdh & Glyceraldehyde-3-phospate dehydrogenase & ACTTACGAGCAGATCAAAGCAGTTTCACGAAGTTGTCGTT & 170 & $(12)$ \\
\hline
\end{tabular}

pronounced on the MDR E. coli strain compared to the pump-deleted $E$. coli strain. This activity suggests that the compound may interfere with the proton motive force because AcrB utilizes proton motive force as energy for its transport function.

The P-ylides were not able to inhibit the QS in the applied systems compared to the positive control AO (data not shown).

Regarding the effect of P-ylides on the relative expression of efflux pump and QS genes in E. coli AG100, the most effective compounds $\mathbf{2}, \mathbf{4}$, and $\mathbf{5}$ were selected for geneexpression studies. In the assay, the gene of the multidrug efflux pump subunit AcrB, the gene of the periplasmic AcrA subunit, the component of the E. coli mar locus (multiple antibiotic resistance), and the gene of the LuxR homolog SdiA were investigated. As shown in Figure 1A, compound 2 at $50 \mu \mathrm{g} / \mathrm{ml}$ up-regulated all the genes studied after $4 \mathrm{~h}$ of exposure, however, after $18 \mathrm{~h}$, the gene expression returned to basal levels. Compound $\mathbf{4}$ also significantly up-regulated the secondary RND transporter gene $a c r B$ (approximately 2fold increase) after $4 \mathrm{~h}$ and $18 \mathrm{~h}$ exposures as well. Surprisingly, there was up-regulation of $s d i A$ expression after $18 \mathrm{~h}$ compared to the expression level after $4 \mathrm{~h}$ implicating the ability of compound 2 to influence the QS gene sdiA, however, this increase was not significant (Figure 1B). Compound 5 up-regulated the expression levels of acr $A$ and $a c r B$ after $4 \mathrm{~h}$, although after $18 \mathrm{~h}$, the up-regulation of these genes was not significant (less than 2-fold increase) as presented by Figure 1C.

\section{Discussion}

Some phenothiazines and hydantoins are known to be EPIs against both bacteria and cancer cells (13). However, Pylides $\mathbf{3}, \mathbf{7}$ and $\mathbf{8}$ have been shown to have activity against the EPs of cancer cells (8), but not to have activity against the EP of bacteria. It is important to note that $\mathrm{ABC}$ transporters are primary efflux pumps deriving their energy from the hydrolysis of ATP, however, the AcrAB-TolC system is a three-component proton motive force-dependent multidrug efflux system. The most effective compounds in
Table III. Relative final fluorescence index (RFI) for the effect of P-ylides (compounds 1-10) on Escherichia coli AG100 expresing acridine-resistance proteins $A$ and $B$ and the multidrug efflux pump outer membrane factor TolC, and the pump-deleted E. coli AG100A strain at $50 \mu \mathrm{g} / \mathrm{ml}$.

\begin{tabular}{lcc}
\hline Compound & \multicolumn{2}{c}{ RFI $^{\mathrm{a}}$} \\
\cline { 2 - 3 } & AG100 & AG100A \\
\hline $\mathbf{1}$ & 0.36 & 0.46 \\
$\mathbf{2}$ & 0.64 & 0.49 \\
$\mathbf{3}$ & 0.04 & 0.12 \\
$\mathbf{4}$ & 0.73 & 0.46 \\
$\mathbf{5}$ & 0.42 & 0.27 \\
$\mathbf{6}$ & 0.25 & 0.49 \\
$\mathbf{7}$ & 0.02 & 0 \\
$\mathbf{8}$ & 0 & 0.19 \\
$\mathbf{9}$ & 0.29 & 0.32 \\
$\mathbf{1 0}$ & 0.42 & 0.44 \\
\hline
\end{tabular}

aRFI was calculated according to the formula:

$$
R F I=\frac{R F_{\text {treated }}-R F_{\text {untreated }}}{R F_{\text {untreated }}}
$$

where $R F_{\text {treated }}$ is the relative fluorescence at the last point (30 min) of the ethidium bromide (EB) retention curve in the presence an P-ylide and $R F_{\text {untreated }}$ is the relative fluorescence at the last point $(30 \mathrm{~min}$ ) of the EB retention curve of the untreated solvent control dimethyl sulfoxide.

the present bacterial system were compounds $\mathbf{2}, \mathbf{4}$, and $\mathbf{5}$, which inhibited the AcrAB-TolC system and influenced the expression of the genes $\operatorname{acr} A$ and $\operatorname{acr} B$, which are constituents of the AcrAB-TolC system. In addition, although the compounds are not QS inhibitors, compound 4 did increase the expression of $s d i A$ after $18 \mathrm{~h}$ exposure.

It can be concluded that in the $\mathrm{COCF}_{3}$ series (compounds 1-6), the MDR-reverting activity in the MDR E. coli strain was intensified in the following order: $\mathrm{CHO}(4)>\mathrm{OMe}(2)$, COMe (5) $>\mathrm{CO}_{2} \mathrm{Et}(\mathbf{6}), \mathrm{COPh}(\mathbf{3}), \mathrm{CN}$ (1). 
Thus, some structurally related trifluoroacetylated P-ylides differ in their MDR-reversal activities between cancer cells and bacterial strains, indicating that the compounds differently act as inhibitors of primary (ABCB1) and secondary (AcrB) efflux pumps because these pumps differ in their energy source for driving the pump (ATP and PMF, respectively).

The present study demonstrated that trifluoroacetylated $\mathrm{P}$ ylides may be attractive lead EPIs for further development as a MDR-reversing agents, however, their mode of action should be elucidated by structure-activity relationship studies.

\section{Acknowledgements}

This research was supported by the Szeged Foundation for Cancer Research, the European Union and the State of Hungary, cofinanced by the European Social Fund in the framework of TÁMOP 4.2.4. A/2-11-1-2012-0001 'National Excellence Program'. This article was supported by the János Bolyai Research Scholarship of the Hungarian Academy of Sciences.

\section{References}

1 Tanwar J, Das S, Fatima Z and Hameed S: Multidrug resistance: an emerging crisis. Interdiscip Perspect Infect Dis 541340. doi: 10.1155/2014/541340, 2014.

2 Nikaido H: Multidrug resistance in bacteria. Annu Rev Biochem 78: 119-146, 2009.

3 Nikaido H and Pagès JM: Broad-specificity efflux pumps and their role in multidrug resistance of Gram-negative bacteria. FEMS Microbiol Rev 36: 340-363, 2012.

4 Kanamaru K, Kanamaru K, Tatsuno I, Tobe T and Sasakawa C: SdiA, an Escherichia coli homologue of quorum-sensing regulators, controls the expression of virulence factors in enterohaemorrhagic Escherichia coli O157:H7. Mol Microbiol 38: 805-816, 2000.

5 Tavío MM, Aquili VD, Poveda JB, Antunes NT, SánchezCéspedes J and Vila J: Quorum-sensing regulator sdiA and marA overexpression is involved in in vitro-selected multidrug resistance of Escherichia coli. J Antimicrob Chemother 65: 1178-1186, 2010
6 Lee J, Maeda T, Hong SH and Wood TK: Reconfiguring the quorum-sensing regulator SdiA of Escherichia coli to control biofilm formation via indole and $\mathrm{N}$-acylhomoserine lactones. Appl Environ Microbiol 75: 1703-1716, 2009.

7 El-Batta A, Jiang C, Zhao W, Anness R, Cooksy AL and Bergdahl M: Wittig reactions in water media employing stabilized ylides with aldehydes. Synthesis of alpha,betaunsaturated esters from mixing aldehydes, alpha-bromoesters, and $\mathrm{Ph} 3 \mathrm{P}$ in aqueous NaHCO3. J Org Chem 72: 5244-5259, 2007.

8 Spengler G, Ocsovszki I, Tönki Ás, Saijo R, Watanabe G, Kawase $\mathrm{M}$ and Molnár J: Fluorinated $\beta$-diketo phosphorus ylides are novel inhibitors of the ABCB1 efflux pump of cancer cells. Anticancer Res 35: 5915-5919, 2015.

9 Clinical and Laboratory Standard Institute guidelines. http://clsi.org/

10 Viveiros M, Martins A, Paixão L, Rodrigues L, Martins M, Couto I, Fähnrich E, Kern WV and Amaral L: Demonstration of intrinsic efflux activity of Escherichia coli K-12 AG100 by an automated ethidium bromide method. Int J Antimicrob Agents 31: 458-462, 2008

11 Varga GZ, Szabo MA, Schelz Zs, Szegedi E, Amaral L and Molnár J: Quorum sensing inhibition by phenothiazines and related compounds. Lett Drug Design Discovery 8: 133-137, 2011.

12 Viveiros M, Dupont M, Rodrigues L, Couto I, Davin-Regli A, Martins M, Pagès JM and Amaral L: Antibiotic stress, genetic response and altered permeability of E. coli. PLoS One 2: e365, 2007.

13 Amaral L, Spengler G, Martins A, Armada A, Handzlik J, KiecKononowicz $\mathrm{K}$ and Molnar $\mathrm{J}$ : Inhibitors of bacterial efflux pumps that also inhibit efflux pumps of cancer cells. Anticancer Res 32: 2947-2957, 2012.
Received July 22, 2016

Revised August 29, 2016

Accepted September 5, 2016 